University of Louisville

ThinkIR: The University of Louisville's Institutional Repository

Electronic Theses and Dissertations

$5-2017$

\title{
Environmental factors, not plants, contribute to functional diversity of soil bacteria in the dunes of lake michigan.
}

Andrea Stark Howes

University of Louisville

Follow this and additional works at: https://ir.library.louisville.edu/etd

Part of the Ecology and Evolutionary Biology Commons

\section{Recommended Citation}

Howes, Andrea Stark, "Environmental factors, not plants, contribute to functional diversity of soil bacteria in the dunes of lake michigan." (2017). Electronic Theses and Dissertations. Paper 2674.

https://doi.org/10.18297/etd/2674

This Master's Thesis is brought to you for free and open access by ThinkIR: The University of Louisville's Institutional Repository. It has been accepted for inclusion in Electronic Theses and Dissertations by an authorized administrator of ThinkIR: The University of Louisville's Institutional Repository. This title appears here courtesy of the author, who has retained all other copyrights. For more information, please contact thinkir@louisville.edu. 
ENVIRONMENTAL FACTORS, NOT PLANTS, CONTRIBUTE TO FUNCTIONAL DIVERSITY OF SOIL BACTERIA IN THE DUNES OF LAKE MICHIGAN

\author{
By \\ Andrea Stark Howes \\ B.S., University of Louisville, 2015

\begin{abstract}
A Thesis
Submitted to the Faculty of the

College of Arts and Sciences of the University of Louisville

In Partial Fulfillment of the Requirements

For the Degree for
\end{abstract}

\author{
Master of Science \\ In Biology
}

\author{
Department of Biology \\ University of Louisville \\ Louisville, Kentucky
}

May 2017 

ENVIRONMENTAL FACTORS, NOT PLANTS, CONTRIBUTE TO FUNCTIONAL

\title{
DIVERSITY OF SOIL BACTERIA IN THE DUNES OF LAKE MICHIGAN
}

\author{
By \\ Andrea Stark Howes \\ B.S., University of Louisville, 2015 \\ A Thesis Approved on
}

April 25, 2017

By the following Thesis Committee:

\begin{tabular}{c}
\hline Dr. Sarah Emery \\
\hline Dr. Susanna Remold \\
\hline Professor Robert Forbes
\end{tabular}




\section{ACKNOWLEDGMENTS}

I would like to thank my primary adviser, Dr. Sarah Emery, for her constant support and guidance. I would also like to thank my other committee members, Dr. Remold and Professor Forbes, for their advice. I would also like to thank Matthew Reid for allowing me to assist with data collection during his Michigan dune field survey in July of 2015. I would also like to thank the Garden Club of America for funding Matthew Reid and the field trip used to gather these field data. I would also like to thank the entire Emery lab for their support. Lastly, I would like to thank my parents, Andrew and Daphne Howes. 


\title{
ABSTRACT \\ ENVIRONMENTAL FACTORS, NOT PLANTS, CONTRIBUTE TO FUNCTIONAL DIVERSITY OF SOIL BACTERIA IN THE DUNES OF LAKE MICHIGAN
}

\author{
Andrea Stark Howes
}

April 25, 2017

Soil bacteria play important roles in nutrient cycling and other ecosystem functions, and many biotic and abiotic factors can influence bacterial functional diversity. The goal of this field study was to examine differences among bacterial communities in sand dunes of Lake Michigan. I used Biolog Ecoplates ${ }^{\mathrm{TM}}$ to compare bacteria functional diversity associated with four different plant species: the native dune-building grass Ammophila breviligulata, invasive species Leymus arenarius and Gypsophila paniculata, and native legume Lathyrus japonicus across 13 sites in Michigan, representing a gradient in abiotic factors such as precipitation and temperature. I found no differences in bacterial function associated with plant species, but did find strong effects of precipitation, elevation, organic matter, plot distance from forest, and latitude. I conclude that abiotic and edaphic factors played a much larger role in shaping bacteria community function than changes in plant species. 
TABLE OF CONTENTS

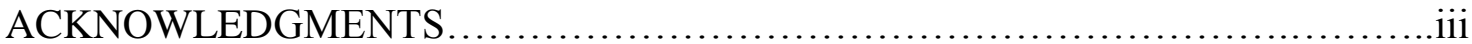

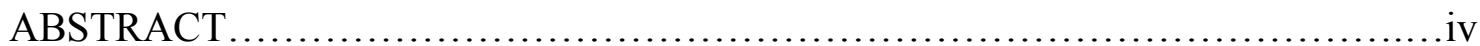

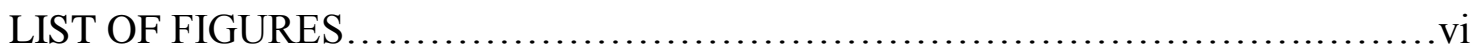

INTRODUCTION............................................................

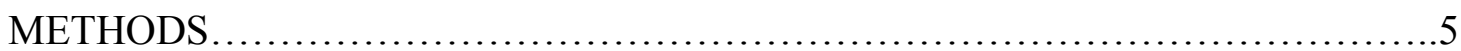

RESULTS.............................................................. 11



FUTURE DIRECTIONS ............................................... 16

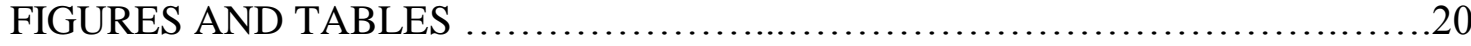

REFERENCES........................................................... 29

CURRICULUM VITA...................................................... 33 


\section{LIST OF FIGURES}

$\begin{array}{lll}\text { FIGURE PAGE } & \text { PAR }\end{array}$

1. Map of Michigan Dune Parks Sampled........................................20

2. Snapshot of Dune Landscape Analysis....................................22

3. Ordination of bacteria function under Leymus and Ammophila ...................25

4. Ordination of grouped bacteria function under Leymus and Ammophila............26

5. Ordination of bacteria function under Ammoph, Gypsoph, and Lathyrus.............27

6. Ordination of grouped bacteria function under Ammoph, Gypsoph, and Lathyrus.....28 


\section{INTRODUCTION}

Until recently aboveground ecosystems were given more consideration than below-ground ecosystems for informing ecologists' understanding of the role of species interactions in structuring communities and regulating ecosystem function. While the importance of aboveground species interactions cannot be denied, ecologists now understand that soil organisms can also directly affect ecosystem processes (Bardgett and van der Putten 2014). Soil bacteria in particular play a vital role in maintaining ecosystem function both above- and belowground. Dead plant litter is the primary form of energy entering the soil ecosystem. Bacteria (and fungi) convert this dead matter into forms that can be used again by plants. For example, in many ecosystems, nitrogen mineralization rates by soil organisms largely determine the amount of nitrogen available for plants (Bardgett and Bardgett 2007). Nitrogen fixation, also a process completed by bacteria, adds to the amount of consumable nitrogen available to plants in many ecosystems (Ledgard and Steele 1992). Phosphorous, another vital nutrient for plant survival, is primarily made available in the soil through microbe solubilization of inorganic phosphorous (Bardgett and Bardgett 2007). It is important to study the factors that affect soil bacteria because both abundance and species composition of bacterial communities impact nutrient cycling and plant performance. This, in turn, impacts the rest of the ecosystem (Bais, Weir et al. 2006). 
Many factors have significant effects on bacterial communities in the soil. Plant identity is thought to play a role in the types of bacteria located in the rhizosphere, the area closest to plant roots. Carbon compounds in root exudates that bacteria consume can be highly plant species specific (Shukla et al. 2011), often resulting in unique rhizosphere bacterial communities. The difference between rhizospheres can be large or small depending on the ecosystem, the plant species compared, and the bacterial species studied. For example, when saponin, a root exudate, was added to a clover plant's rhizosphere the two dominant bacteria populations disappear and were replaced with a bacteria species that commonly exists in rhizospheres that naturally contain saponin (Fons, Amellal et al. 2003). In contrast, when the rhizospheres of strawberry, potato, and rapeseed plants were studied and their bacteria DNA compared, potato plants and rapeseed plants had very similar rhizospheres when compared to the third plant species that was not an annual (Smalla, Wieland et al. 2001).

When plant identity and soil bacteria interactions are studied it is often in an attempt to understand how invasive plants establish and spread. It is well established that invasives can benefit from a novel soil microbial community when they invade a new ecosystem (Chen, Zheng et al. 2013). An invasive plant's success is often contributed, at least in part, to escape from pathogenic interactions with the home soil microbial community (Reinhart and Callaway 2006). There is growing research that shows that some invasive plants also alter their new soil microbial community as they invade (Belnap and Phillips 2001, Klironomos 2002, Kuske, Ticknor et al. 2002, Duda, Freeman et al. 2003). For example, Japanese barberry and Japanese stilt grass invasions were studied in a hardwood forest in New Jersey. The microbial communities under these two 
invasive plants differed significantly in both structure and function when compared to the native plants in the same location (Kourtev, Ehrenfeld et al. 2002). An invasive plant's relationship with native soil microbes impacts the invasive plant's ability to compete with native plants (Berg and Smalla 2009). Widespread changes in the soil microbial community could also possibly have an impact on the fitness of native plants in the invaded habitat (Batten, Scow et al. 2006).

Rhizosphere bacterial communities are impacted by many factors other than plant species identity. Biotic and abiotic factors, such as plant health, plant age, grazing animals, weather, season, soil type and age, and pesticides impact soil communities (Fierer and Jackson 2006, Tarlera, Jangid et al. 2008, Berg and Smalla 2009). In fact, quite often the abiotic factors of the ecosystem are the largest force shaping the bacterial community (Zhang, Zhang et al. 2013). A field study in the upper and lower Arctic regions found that the change in location between high and low Arctic sites was responsible for differences seen in the phenotypic fingerprint of rhizosphere bacterial communities in the two regions and that bacterial function was more different between the two sites than it was between the rhizospheres of different plant species (Kumar, Mannisto et al. 2016). Another study looked at rhizosphere bacteria communities in a salt-marsh habitat and found that, while bacterial communities can be related to particular plant species they are associated with, these associations can be swamped by site-to-site differences in abiotic factors (Rietl, Overlander et al. 2016). The relative importance of specific biotic or abiotic factors in controlling the function of soil bacteria varies depending on the ecosystem and the current conditions. 
In this study I ask: 1) Does plant species identity significantly alter the soil bacteria community functional diversity? and 2) Do abiotic factors significantly alter bacteria community functional diversity? This study compares soil bacteria communities associated with two invasive plant species, Leymus arenarius and Gypsophila paniculata, one native legume, Lathyrus japonicus, and one dominant native grass, Ammophila breviligulata, across a range of environmental conditions on the dunes of Lake Michigan. 


\title{
METHODS
}

\author{
Study System
}

The dune system of the Great Lakes has been studied extensively since the late 1800s, partially because it is a classic example of primary succession (Cowles 1899). The foredune is the portion of the dunes closest to the beach. It is the area where sand first begins to accumulate due to the pioneering grasses present (Albert 2000). All plants that live on the foredunes must be tolerant of frequent sand burial (Albert 2000). Ammophila breviligulata (American beachgrass) is the dominant grass on the Great Lake dunes. It is an ecosystem engineer, using its extensive root system to stabilize the dunes that it inhabits (Emery, Bell-Dereske et al. 2015). Lathyrus japonicus (beach pea) is a native herbaceous legume that also grows on these foredunes. Other plants native to these foredunes include sand reed, sand cherry, creeping juniper, wormwood, and common milkweed (Albert 2000). Several non-native plants have become invasive on the dunes of Lake Michigan in recent years. These exotic plants are a threat to native foredune plants because they over-stabilize the sand, altering the environment that native plants evolved to thrive in (Albert 2000). One of these invasive plants, Gypsophila paniculata (baby's breath), has been an invasive in this habitat since the 1960s. It has been shown to alter arthropod communities when it invades (Baskett, Emery et al. 2011). However, 
Gypsophila paniculata has not been found to have any effect on the arbuscular mycorrhizal fungi that associate with plant roots (Emery, Doran et al. 2013). Leymus arenarius is a second invasive plant on the Michigan foredunes. Like Gypsophila it has been present on these dunes since the 1960s (Larkin 2012). It has been shown that Leymus benefits more from its relationship with arbuscular mycorrhizal fungi (in the form of enhanced growth) than the native Ammophila does (Reid and Emery 2017). While the findings above show that the invasive plants on the dunes of Lake Michigan can alter some species interactions, none of the research on these invasive plants has centered on the effects that invasive plants could be having on the soil bacteria in the rhizosphere.

\section{Site Descriptions and Soil Sampling}

In July 2015, Ammophila breviligulata, Lathyrus japonicus, Leymus arenarius, and Gypsophila paniculata populations on the southern dunes of Lake Michigan were surveyed in 13 national parks, state parks, county parks, and regional land conservancies (Fig. 1). Wherever populations of target species (Leymus, Lathyrus, or Gypsophila) were found, a 20 meter transect was established running parallel to the lakeshore through the target population. 20 soil cores (15cm deep) were taken from each transect. GPS were taken at each plot to record the latitude, longitude, and elevation. Soil samples from 13 transects of Leymus arenarius were taken in total. 3 Gypsophila transects were taken in total. 4 Lathyrus transects were taken in total. (Table 1). Paired transects through 
Ammophila breviligulata populations were sampled 20 meters north or south of each target species transect. Plant species richness, percent detritus (litter cover), percent bare soil, and percent vegetation were recorded based on visual estimation for all transects. The soil samples were stored in coolers with ice until they could be transported to the lab. Soil samples were then stored in refrigerators at $4^{\circ} \mathrm{C}$ until analyses.

\section{Bacteria Community Function Analysis}

Biolog Ecoplates ${ }^{\mathrm{TM}}$ contain 31 carbon substrates (Table 2) that are used to profile microbe carbon consumption. Each Ecoplate ${ }^{\mathrm{TM}}$ contains three replicates of each substrate and three replicates of a "blank" well that has no carbon substrate. Each well also has a tetrazolium dye that creates the color purple when respiration occurs inside the well, indicating ability of the microbe community to use the given carbon substrate (BIOLOG Inc, Hayward, CA, USA). The extraction and pipetting of soil bacteria onto Ecoplates followed the protocol described by (Chen, Zheng et al. 2013). Briefly, 5g soil from each transect was placed in a sterile $50 \mathrm{~mL}$ centrifuge tube. $45 \mathrm{~mL}$ of sterile $0.85 \% \mathrm{NaCl}$ was added using a sterile pipet. The centrifuge tube was then shaken at $300 \mathrm{rpm}$ for 30 minutes and allowed to settle for 5 minutes. $5 \mathrm{~mL}$ of the solution, extracted from the middle of the centrifuge tube, was combined with another $45 \mathrm{~mL}$ sterile $0.85 \% \mathrm{NaCl}$. This second solution was then vortexed for 10-30 seconds to mix the two liquids. $150 \mathrm{uL}$ of this 1:100 solution was pipetted into each well of a room temperature EcoPlate ${ }^{\mathrm{TM}}$ (BIOLOG Inc, Hayward, CA, USA). The Ecoplate then sat for an hour before running 
through the plate reader at $595 \mu \mathrm{m}$ wavelength for baseline consumption data (time $=0$.)

Plates were then read at day 7 at $595 \mu \mathrm{m}$ wavelength (BioTek, ELx800) after popping any bubbles that have formed on the surface of the wells with a sterile plastic toothpick.

\section{Quantification of Soil Organic Matter}

Organic matter content in sample soil was calculated using the ash-free massing method (Ryan, Melillo et al. 1990). 20g of air dried soil from each transect was placed in a ceramic crucible and burned in a muffle furnace at $475^{\circ} \mathrm{C}$ for 4 hours. The muffle furnace was then turned off and the soil allowed to cool. The soil was reweighed and the new weight was subtracted from the beginning weight and the quotient multiplied by 100 to obtain the percent of organic matter in the soil. This procedure was completed for all soil samples.

\section{Climate Data}

The latitude and longitude for each sample transect was used to gather average daily temperature high and average daily precipitation for the month of July 2015 using PRISM: Data Explorer (http://prism.oregonstate.edu.) The PRISM data used are an estimated average for the month based on gridded $4 \mathrm{~km}^{2}$ cells. PRISM uses reporting stations across the United States and assigns them weight for a particular location based 
on similarity to the particular grid cell in question. These similarities include location, coastal proximity, and elevation (Daly, Halbleib et al. 2008). PRISM then uses regression algorithms to estimate averages for the specific grid cell (PRISM Climate Group, Oregon State University, http://prism.oregonstate.edu).

\section{Geographic variables}

ArcMap (ESRI 2011) was used to plot the coordinates of the transects of all sampling sites. A 2014 aerial image base-map (ESRI 2011) was then overlaid. The distances were then measured between each sample site and the forest edge, the Lake Michigan edge, and the dune edge (where the dune vegetation and beach meet) (Fig. 2).

\section{Data Analyses}

A non-metric multidimensional scaling (NMS) ordination was performed using the Biolog plate reader data to visualize the differences in bacterial functional diversity potential using PC-ORD v.12 (McCune 1999). Data from Leymus arenarius transects and corresponding Ammophila breviligulata transects were analyzed separately from Gypsophila paniculata and Lathyrus japonicus samples (with corresponding Ammophila data) to control for differences in storage times for soils used in the Biolog Ecoplate ${ }^{\mathrm{TM}}$ procedure. A multi-response permutation procedure (MRPP) was then run to analyze 
differences in bacterial functional diversity between plant species (McCune 2002).

Abiotic variables associated with each sample plot were included as overlays on the NMS when they were correlated with NMS axes by at least $20 \%$. Additionally, biotic variables including the percent of ground cover by detritus, percent bare sand, plant species richness, and percent Ammophila cover were also included as overlays for the comparison of Leymus and Ammophila only. All analyses were conducted a second time, with Ecoplate ${ }^{\mathrm{TM}}$ carbon substrates grouped by substrate type into carbohydrates, carboxylic acids, amino acids, amines, phosphorylated compounds, and polymers (Table 2). 


\section{RESULTS}

MRPP analyses for all ordinations indicate that soil bacteria function did not significantly differ between plant species (Fig. 3-6). The NMS ordination of Leymus and Ammophila indicates that the carbon usage profiles by soil bacteria were significantly associated with organic matter content of the soil, the average temperature high, the distance of the site from the forest, percent ground covered by detritus, and the latitude (Fig. 3). The majority of these significant correlations remain when bacterial carbon usage is grouped into six carbon substrate types (Fig. 4). Percent detritus ground cover was the only abiotic/edaphic factor that was no longer significant when the carbon substrates were grouped. The NMS ordination of Gypsophila, Lathyrus, and Ammophila samples indicate that the carbon usage profiles by soil bacteria was significantly associated with average temperature, distance from the forest, and the percent of organic matter in the soil (Fig. 5). Organic matter and distance from forest remained associated with bacterial function when Ecoplate data were grouped by substrate type (Fig. 6). 


\section{DISCUSSION}

Although other studies in different ecosystems have shown that plants can alter soil bacteria community function in the rhizosphere (Smalla, Wieland et al. 2001), that does not seem to be the case in this dune system. My analyses showed no difference between the bacteria function profiles in the rhizospheres of different plant species. It could be that the root exudates between functionally similar species such as Leymus and Ammophila are too similar to cause any changes in the function of bacteria in their rhizospheres. However, the functionally distinct species Gypsophila paniculata, Lathyrus japonicus, and Ammophila breviligulata also showed no difference in the bacterial function in their rhizospheres. Lathyrus japonicus is a nitrogen fixing plant, and was expected to impact bacterial function due to increased soil nitrogen (Ramirez 2011). Gypsophila paniculata is a non-native forb with a large taproot (Coupland 1966) rather than the spreading fibrous roots of Ammophila, but there was still no difference in the function of their associated bacterial communities.

Our analyses showed that many abiotic factors are more significant contributors to bacterial community function than plant identity. When comparing Leymus and Ammophila, the average site temperature high, organic matter content of the soil, the distance of the site from the forest, percent ground covered by detritus, and latitude were all significantly correlated with bacterial community functional diversity. Similarly, average temperature, distance from the forest, and the percent of organic matter in the 
soil were important in the comparison between Gypsophila, Lathyrus, and Ammophila. It is not surprising that bacterial community function varies in response to climate.

Research done in hardwood forest ecosystems found that as the temperature increases due to global warming, the amount of carbon substrate that is accessible to soil bacteria for respiration increases. This corresponded to a change in lipids in the bacterial lipid membranes and the kinetic ability of bacteria to respire (Zogg, Zak et al. 1997). However, results from studies on soil bacteria and their relationship with temperature vary depending on the ecosystem studied and the other variables included. Other research has found that soil warming alters soil bacteria functional composition, but the effect is significantly smaller than the effects of other factors such as soil moisture (Zhang, Zhang et al. 2013). Bacteria functional changes that correlate with temperature differences on the dunes of Lake Michigan indicate that these functions could also shift in response to climate change. The temperature gradient between the plots in this research was usually less than $5^{\circ} \mathrm{C}$. This is an indication that a small shift in climate could have an effect on the bacterial community. Some research has predicted lower levels of water in the Great Lakes due to climate change increasing the rate of evapotranspiration (Gronewold, Fortin et al. 2013). Water availability is known to effect the function of soil bacteria (Zhang, Zhang et al. 2013). These factors, when combined, suggest that climate change will have a significant impact on the function of bacteria on the dunes of Lake Michigan. Altered or reduced soil bacteria functional diversity due to a large-scale temperature change would likely mean reduction in the ecosystem services that soil bacteria provide (van der Heijen 2008). Some studies have shown that a decrease in bacteria functional diversity corresponds to a decrease in decomposition and nitrogen leaching rates (Bonkowski and 
Roy 2005). This microbial diversity effect is strongest when there are few microbes present, such as primary successional habitats (Setala and McLean 2004). This is likely because there is functional redundancy in the ecosystem function of many soil bacteria species.

The amount of soil organic matter significantly influenced the soil bacteria community function as well. Organic matter content tends to increase with increased successional age on sand dunes (De Deyn, Cornelissen et al. 2008). In roughly 100 years, Ammophila breviligulata is replaced with shrubs that are better suited to the environment that the previous dune-building grass has created (Lichter 1998). Bacterial biomass has been shown to decrease while fungal biomass increases along a sand dune successional gradient. This decrease in bacteria biomass is thought to be partially due to the change in quality of organic matter (Pennanen, Strommer et al. 2001). Similarly, functional diversity in bacteria has been found to change along a glacier successional gradient (Tscherko, Rustemeier et al. 2003). The known change in bacteria biomass along a dune successional gradient combined with the functional change seen in glacier successional studies leads to the conclusion that soil bacteria function also changes on sand dunes as succession proceeds. This would also account for the 'distance from the forest' being one of the significant vectors in the majority of the ordinations formed in this study.

While this study suggests that invasive plants do not significantly alter belowground function of the dune ecosystem, I was only looking through the lens of soil bacteria community function. There are many other ways in which invasive species could be affecting their new dune communities, such as shifting arthropod communities and reducing the populations of threatened native plants (Emery and Doran 2013). The effects 
of invasive plants on the dunes are not fully understood. The park systems in Michigan spend a considerable amount of time attempting to control plants that have invaded the dunes (Leege and Kilgore 2014). If these efforts were to end it is very likely that a more complete invasion would have numerous effects on the dune ecosystem. 


\section{FUTURE DIRECTIONS}

\section{A. A future Michigan dune survey:}

\section{Do soil bacteria communities differ genetically in response to plant identity?}

This thesis centered on the functional diversity of soil bacteria and the factors that alter this functional diversity. Functional diversity is important because carbon consumption is largely how soil bacteria impact their ecosystem. However, genetic diversity of soil bacteria is just as important when viewed through an evolutionary perspective. Studies like (Kumar, Mannisto et al. 2016) which look at both functional and genetic diversity in soil bacteria compared between plant species and location provide a broader picture of the importance of soil bacteria diversity in ecosystems. A comparison of functional and genetic diversity on the dunes of Lake Michigan would offer a much more in-depth insight of what drives soil bacteria diversity. This would allow for comparisons of this dune ecosystem and the bacterial community to other ecosystems. This genetic research would use rRNA amplification, cloning, and sequencing to determine if there actually is a significant genetic difference between the soil communities of the two plant species that was undetectable as a phenotypic difference using the Biolog assays. It could be that there is a great deal of functional redundancy in 
the soil bacteria species on these sand dunes. This would be valuable information from a conservation standpoint.

\section{Is the successional gradient shaping soil bacteria functional community?}

A second dune survey would provide data to examine how soil bacterial diversity changes across successional gradients. The survey conducted for this paper chose soil samples wherever particular invasive plant species were found. Only later, with GIS information, did it become apparent that the successional gradient could be having a significant effect on soil bacteria function. It would be worthwhile to purposefully take soil samples along the successional gradient of this ecosystem and test the bacteria using the Biolog Ecoplate ${ }^{\mathrm{TM}}$ method to determine how large this effect is. Running a transect from the forest's edge to the beach edge and studying both the genetic and functional diversity of the soil bacteria found along the gradient would give a more conclusive answer into how influential the gradient is in shaping bacterial communities.

Successional gradient surveys looking at soil bacterial function have been done with glacier primary succession (Tscherko, Rustemeier et al. 2003) and found that incredibly young soil typically has less functional diversity.

\section{B. Laboratory root exudate extraction and identification}

1. Do root exudates differ significantly between plants on the dunes of Lake Michigan? 
The Biolog Ecoplate ${ }^{\mathrm{TM}}$ and the 31 carbon substrates contained within were the only test for functional diversity within this study. This identifies "potential" carbon use. If the carbon sources in the soil sampled differs from these 31 sources Biolog provides the test is less relevant in the real world. It would be interesting to see if there are differences in types and quantities of root exudates produced by Ammophila breviligulata, Leymus arenarius, Gypsophila paniculata, and Lathyrus japonicus that are not encompassed by these 31 carbon substrates. Extracting dilute root exudates from hydroponically grown plants, concentrating exudates via organic solvents, and then separating components via high performance liquid chromatography (Vranova, Rejsek et al. 2013) would provide knowledge on the exact relevance of the Biolog Ecoplate ${ }^{\mathrm{TM}}$.

\section{Greenhouse experiment}

\section{Does Leymus arenarius alter its rhizosphere to outcompete native dune plants?}

If there are significant genetic differences found in the bacteria in the rhizospheres of the invasive plants vs the native Ammophila breviligulata it would be a good idea to complete a greenhouse experiment to examine the effects that these altered bacteria might have on plant growth. Plant growth promoting bacteria have been shown to enhance plant growth by acting as biofertilizers and reducing stress (Lugtenberg and Kamilova 2009). It is possible that an invasive plant could utilize its rhizosphere differently than a native plant to further its success. A greenhouse study would show if a change in rhizosphere bacteria was a byproduct of different root exudates and held no benefit to the invasive 
plant or if the changed rhizosphere creates a competitive edge for the invasive plant. A greenhouse study would allow for the exclusion of abiotic differences such as temperature, precipitation, and organic matter. This controlled environment would more clearly show the effect that soil bacteria have on invasive dune plants. It could provide a fuller understanding of whether bacteria should be included in the discussion of controlling non-native plants on the dunes of Lake Michigan.

This proposed greenhouse experiment would use Ammophila breviligulata and Leymus arenarius seeds harvested from the Southern dunes of Lake Michigan. Seedlings, first planted in sterile soil, would be crossed with soil bacteria gathered in the field from under both Ammophila breviligulata and Leymus arenarius. Measuring plant growth in this crossed-rhizosphere greenhouse experiment would shed light on whether Leymus arenarius is altering its rhizosphere bacteria in order to outcompete Ammophila breviligulata. Enhanced growth in a simulated drought environment would also provide a glance into how the Leymus arenarius invasion will be altered as atmospheric factors change due to global warming in the next several decades. It is also possible that this future research will show that the Leymus arenarius invasion doesn't affect the soil community to a significant degree. If this is the case, it could be that efforts to identify and remove it from the national parks would be more beneficial if directed elsewhere. 
Figure 1

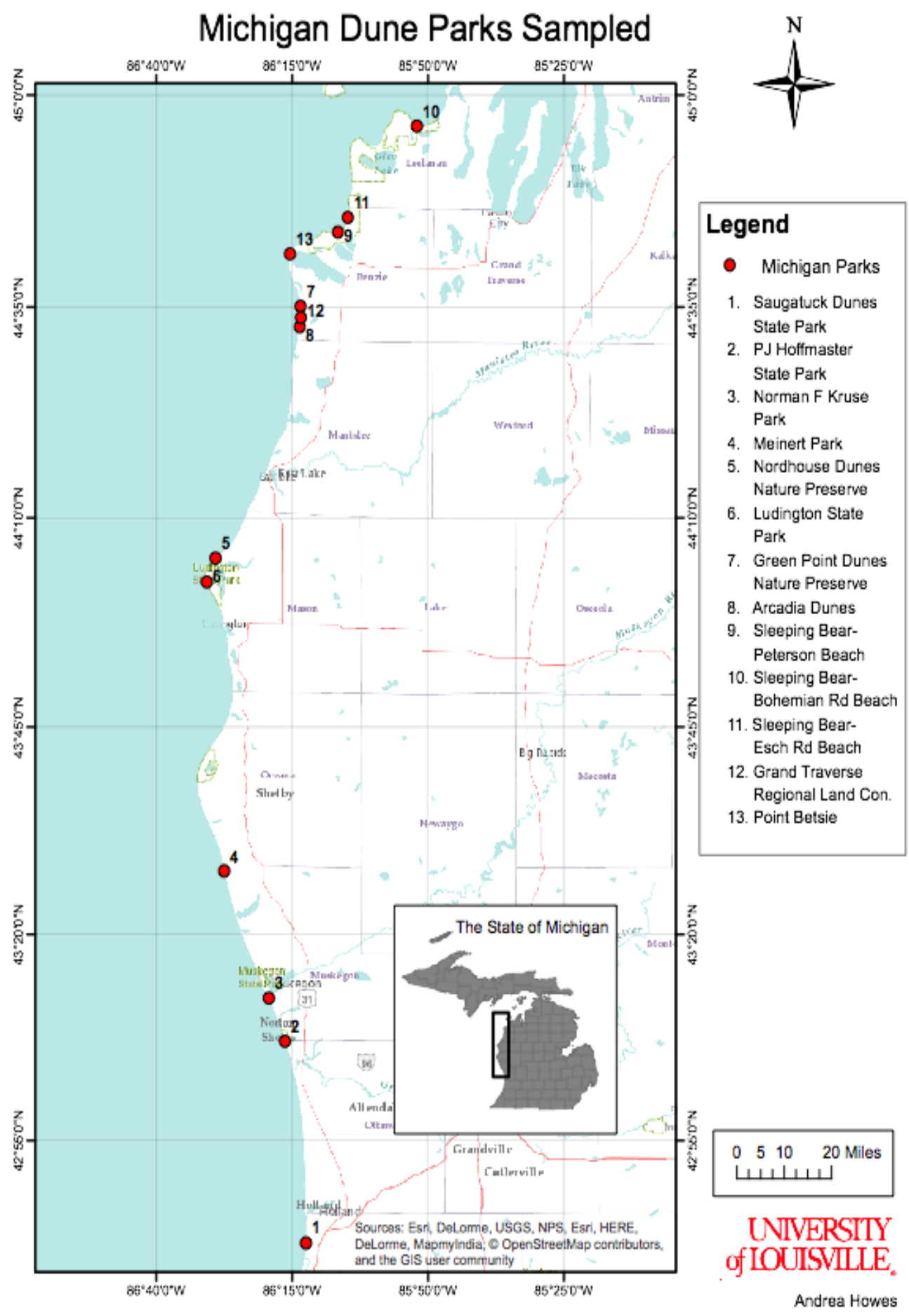

Map of the parks where soil sampling occurred on the eastern coast of Lake Michigan in

July 2015. 


\section{Table 1}

\section{Soil Sampling Summary}

\begin{tabular}{|l|l|l|}
\hline \multicolumn{1}{|c|}{ Park } & Plant species sampled & Total \# of transects \\
\hline Saugatuck Dunes State Park & Leymus & 1 \\
\hline PJ Hoffmaster State Park & Leymus & 4 \\
\hline Norman F Kruse Park & Leymus & 1 \\
\hline Meinert Park & Leymus & 1 \\
\hline Nordhouse Dunes Wilderness Area & Leymus & 2 \\
\hline Ludington State Park & Leymus(2) Lath(1) & 3 \\
\hline Green Point Dunes Nature Preserve & Leymus & 1 \\
\hline Arcadia Dunes & Leymus & 1 \\
\hline Sleeping Bear Dunes (Peterson Beach) & Gypsophila(1) Lath $(1)$ & 2 \\
\hline $\begin{array}{l}\text { Sleeping Bear Dunes (Bohemian Rd } \\
\text { Beach) }\end{array}$ & & 1 \\
\hline Sleeping Bear Dunes (Esch Rd Beach & Gypsophila & 1 \\
\hline Grand Traverse Regional Land Con. & Lathyrus & 1 \\
\hline Point Betsie & Lathyrus & 1 \\
\hline
\end{tabular}

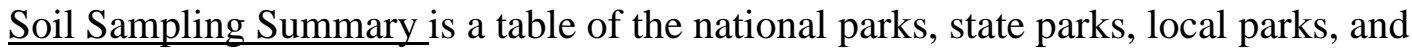
regional land conservancies where soil sampling took place. It includes the types of plants that were found and the overall number of transects taken per park. 


\section{Figure 2:}

Landscape Analysis Snapshot

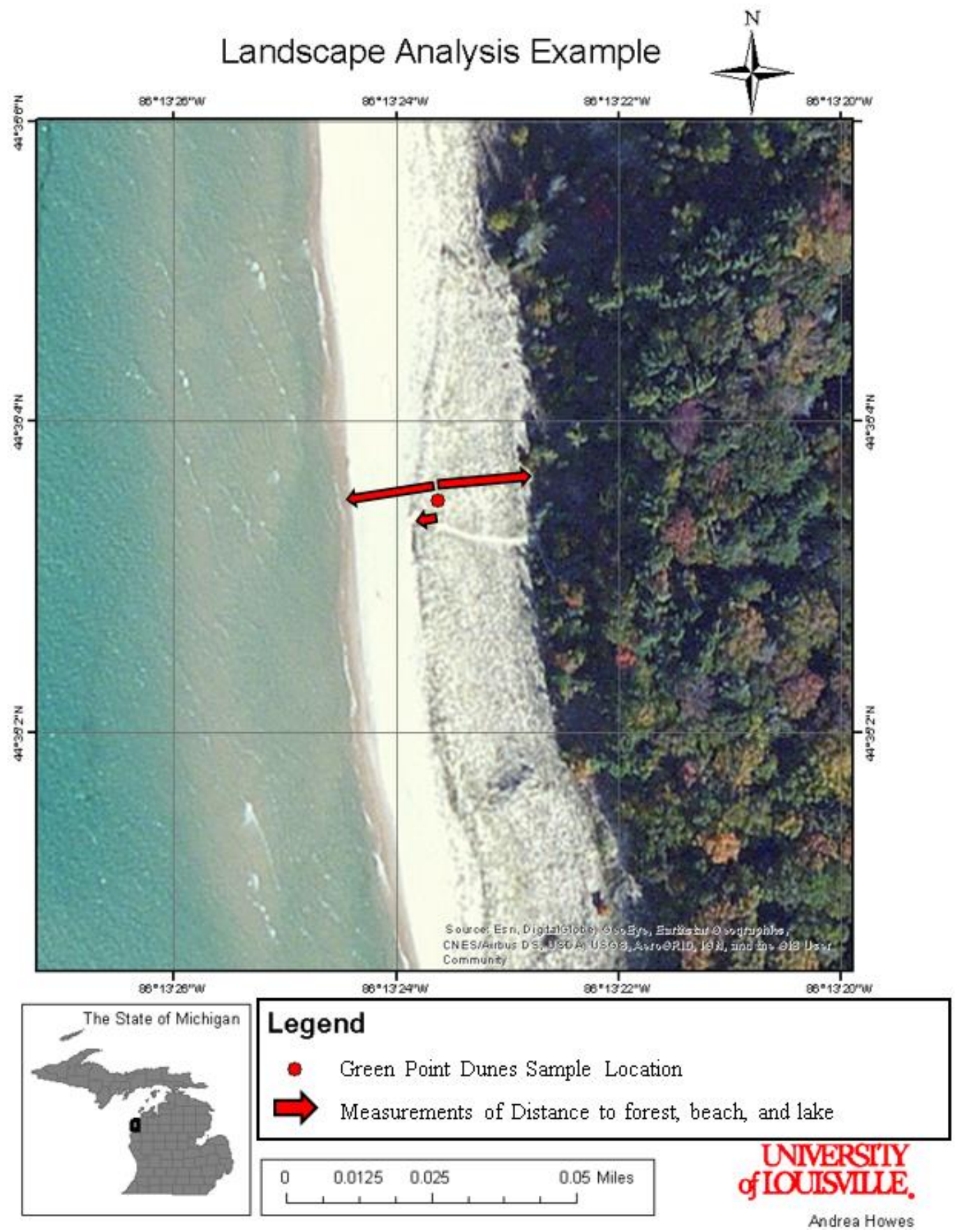

Landscape Analysis Snapshot is an example of the dune landscape analysis completed using ArcMap 2014. Distance from sample site to beach, lake, and forest were measured and then used in the NMS ordination. 


\section{Table 2}

Biolog Ecoplate Functional Groups

\begin{tabular}{|c|c|}
\hline Carbon Substrate & Category \\
\hline Water & control \\
\hline Pyruvic Acid Methyl Ester & carbohydrate \\
\hline Tween 40 & polymer \\
\hline Tween 80 & polymer \\
\hline$\alpha$-cycodextrin & polymer \\
\hline glycogen & polymer \\
\hline D-Cellobiose & carbohydrate \\
\hline$\alpha$-D-Lactose & carbohydrate \\
\hline$\beta$-Methyl-D-Glucoside & carbohydrate \\
\hline D-Xylose & carbohydrate \\
\hline i-Erythritol & carbohydrate \\
\hline D-Mannitol & carbohydrate \\
\hline N-Acetyl-D-Glucosamine & carbohydrate \\
\hline D-Glucosaminic Acid & carboxylic acid \\
\hline Glucose-1- Phosphate & phosphorylated compound \\
\hline D,L- $\alpha$ - Glycerol Phosphate & phosphorylated compound \\
\hline D-Galactonic Acid $\gamma$-Lactone & carboxylic acid \\
\hline D- Galacturonic Acid & carboxylic acid \\
\hline 2-Hydroxy Benzoic Acid & carboxylic acid \\
\hline 4-Hydroxy Benzoic Acid & carboxylic acid \\
\hline$\gamma$ - Hydroxybutyric Acid & carboxylic acid \\
\hline Itaconic Acid & carboxylic acid \\
\hline$\alpha$-Ketobutyric Acid & carboxylic acid \\
\hline D-Malic Acid & carboxylic acid \\
\hline
\end{tabular}




\begin{tabular}{|l|l|}
\hline \multicolumn{2}{|c|}{ Carbon Substrate } \\
\hline L-Arginine & amino acid \\
\hline L-Asparagine & amino acid \\
\hline L- Phenylalanine & amino acid \\
\hline L-Serine & amino acid \\
\hline L-Threonine & amino acid \\
\hline Glycyl-LGlutamic Acid & amino acid \\
\hline Phenylethyl-amine & amine \\
\hline Putrescine & amine \\
\hline
\end{tabular}

Biolog Ecoplate Functional Groups is a list of the 31 compounds found on the Biolog Ecoplates and the functional group categories used to analyze them. 


\section{Figure 3}

$\underline{\text { NMS ordination of carbon function under Ammophila and Leymus plants }}$

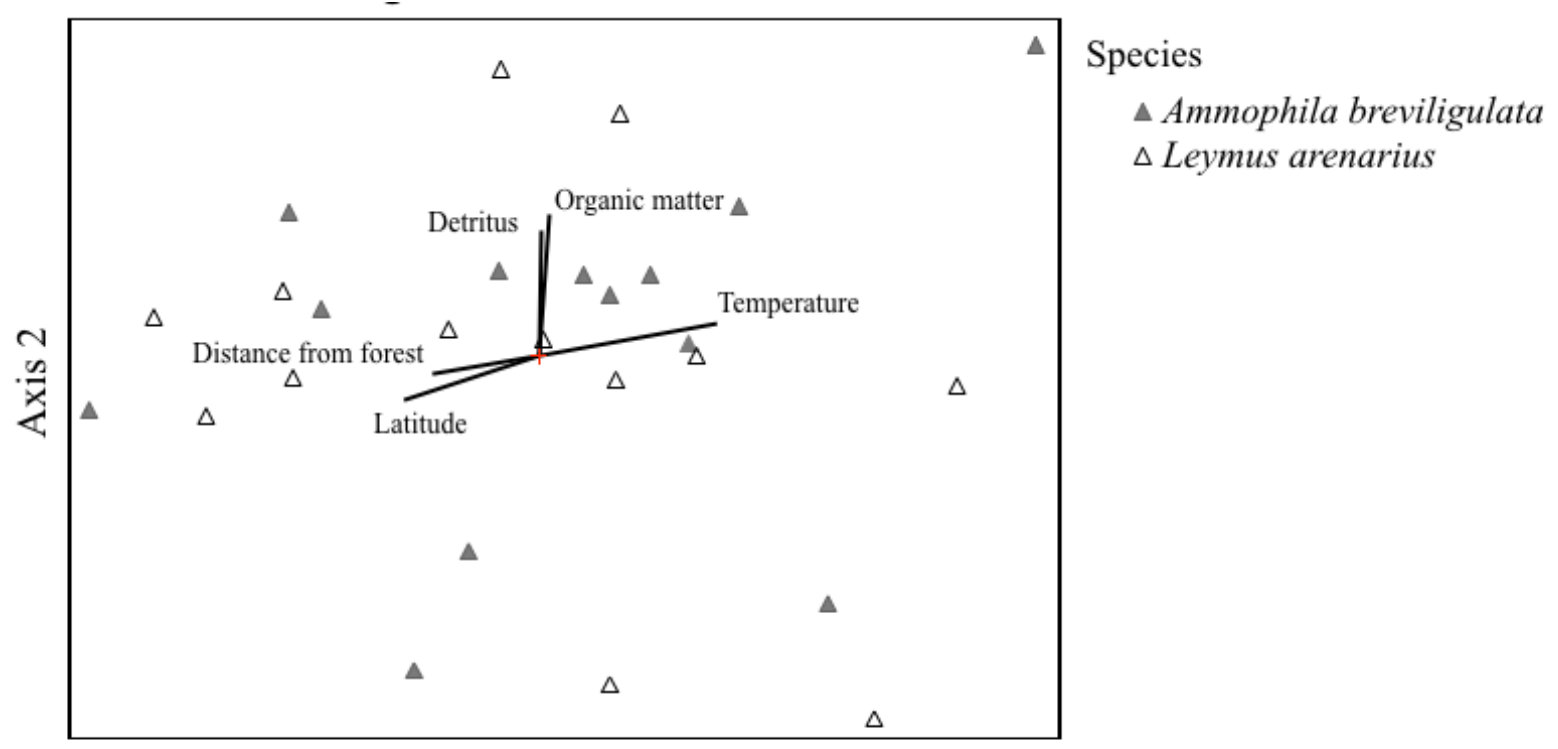

Axis 1

NMS ordination of carbon function under Ammophila and Leymus plants is a visual representation of the variation between Biolog Ecoplates from the soil bacteria found under the Leymus and Ammophila transects. Stress=10.73 Axis 1 explains $58 \%$ of the variation between points, axis 2 explains $23.5 \%$ of the variation between points. $(90.1 \%$ is explained by all three axes). MRPP A statistic=-0.0089 MRPP p-value $=0.839$ 


\section{Figure 4}

NMS ordination of grouped carbon function under Ammophila and Leymus plants

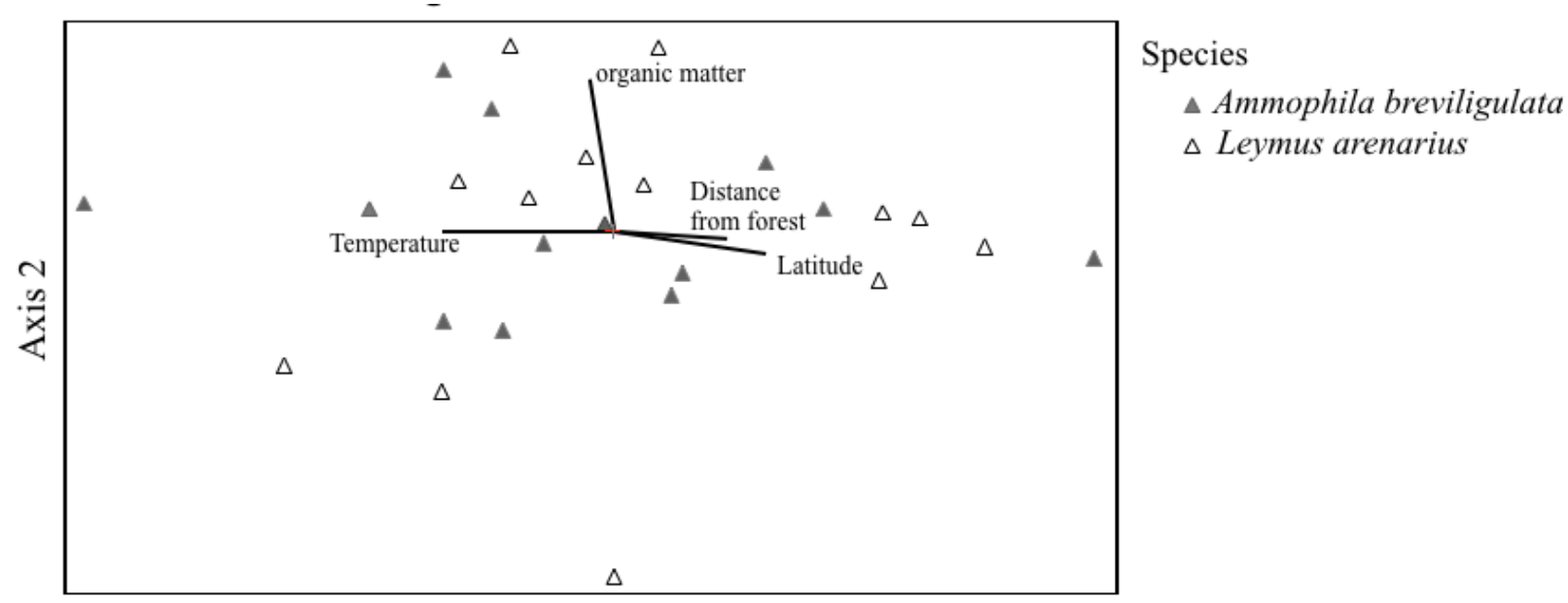

Axis 1

NMS ordination of grouped carbon function under Ammophila and Leymus plants is a visual representation of the variation between Biolog Ecoplates from the soil bacteria found under the Leymus and Ammophila transect while grouping the carbon sources on the Biolog plates into six distinct groups. Stress=10.1 Axis 1 explains $78.4 \%$ of the variation between points, axis 2 explains $16.1 \%$ of the variation between points. $(94.5 \%$ is explained by both axis) MRPP A statistic $=-0.00332$ MRPP $p$-value $=0.453$ 


\section{Figure 5}

NMS ordination of carbon function under Gypsophila, Lathyrus, and Ammophila plants

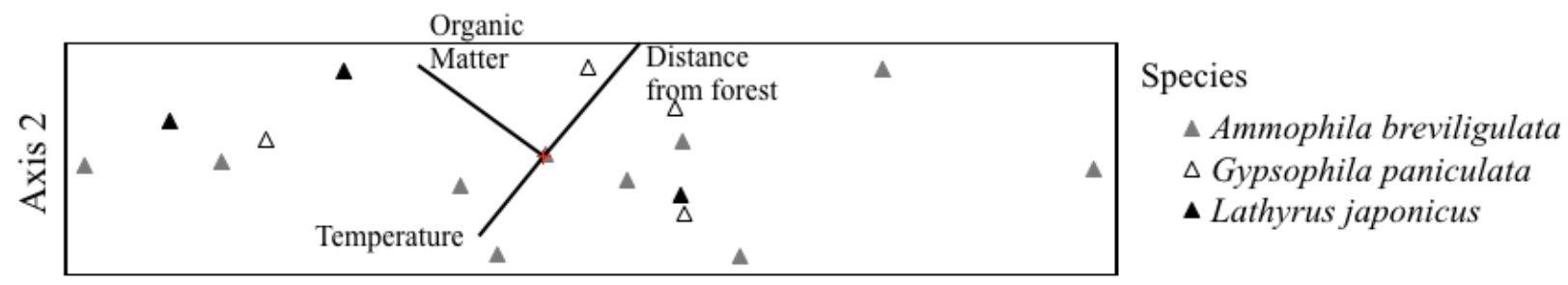

Axis 1

NMS ordination of carbon function under Gypsophila, Lathyrus, and Ammophila plants is a visual representation of the variation between Biolog Ecoplates from the soil bacteria found under the Gypsophila, Lathyrus, and Ammophila plants. Stress=3.302. Axis 1 explains $97.2 \%$ of the variation between points, axis 2 explains $1.2 \%$ of the variation between points. (98.4\% is explained by both axes). MRPP A statistic $=-0.0171$ MRPP pvalue $=0.578$. This NMS ordination was manually set to two dimensions, to enhance visualization of data. 


\section{Figure 6}

NMS ordination of grouped carbon function under Gypsophila, Lathyrus, and Ammophila plants

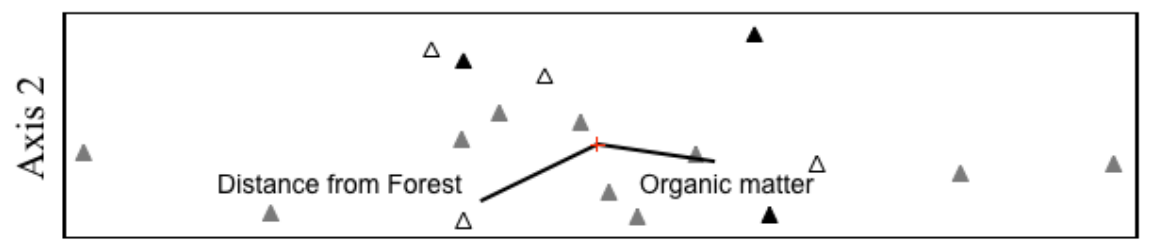

Species

$\triangle$ Ammophila breviligulata

$\triangle$ Gypsophila paniculata

\ Lathyrus japonicus

Axis 1

NMS ordination of grouped carbon function under Gypsophila, Lathyrus, and Ammophila

plants is a visual representation of the variation between Biolog Ecoplates from the soil bacteria found under the Gypsophila, Lathyrus, and Ammophila plants while grouping the carbon sources on the Biolog plates into six distinct groups. Stress $=4.62$ Axis 1 explains $96.7 \%$ of the variation between points, axis 2 explains $2.0 \%$ of the variation between points. (98.5\% is explained by both axis) MRPP A statistic $=-0.028$ MRPP p-value $=$ 0.673 This NMS ordination had to be manually set on two dimensions, as its tendency was to only utilize one dimension. 


\section{REFERENCES}

Albert, D. A. (2000). "Borne of the Wind: An Introduction to the Ecology of Michigan Sand Dunes." Michigan Natural Features Inventory 63.

Bais, H. P., T. L. Weir, L. G. Perry, S. Gilroy and J. M. Vivanco (2006). "The role of root exudates in rhizosphere interations with plants and other organisms." Annual Review of Plant Biology 57: 233-266.

Bardgett, R. D. and R. D. Bardgett (2007). Biology of Soil: A Community and Ecosystem Approach.

Bardgett, R. D. and W. H. van der Putten (2014). "Belowground biodiversity and ecosystem functioning." Nature 515(7528): 505-511.

Baskett, C. A., S. M. Emery and J. A. Rudgers (2011). "Pollinator Visits to Threatened Sprecies are Restored Following Invasive Plant Removal." International Journal of Plant Sciences 172(3): 411-422.

Batten, K. M., K. M. Scow, K. F. Davies and S. P. Harrison (2006). "Two invasive plants alter soil microbial community composition in serpentine grasslands." Biological Invasions 8(2): 217-230.

Belnap, J. and S. L. Phillips (2001). "Soil biota in an ungrazed grassland: Response to annual grass (Bromus tectorum) invasion." Ecological Applications 11(5): 12611275 .

Berg, G. and K. Smalla (2009). "Plant species and soil type cooperatively shape the structure and function of microbial communities in the rhizosphere." Fems Microbiology Ecology 68(1): 1-13.

Bonkowski, M. and J. Roy (2005). "Soil microbial diversity and soil functioning affect competition among grasses in experimental microcosms." Oecologia 143(2): 232240 .

Chen, F., H. Zheng, K. Zhang, Z. Ouyang, J. Lan, H. Li and Q. Shi (2013). "Changes in soil microbial community structure and metabolic activity following conversion from native Pinus massoniana plantations to exotic Eucalyptus plantations." Forest Ecology and Management 291: 65-72.

Coupland, D. (1966). "Life History of Gypsophila paniculata." Weeds 14(4): 313-318. 
Cowles, H. C. (1899). "The Ecological Relations of the Vegetation on the Sand Dunes of Lake Michigan. Part I. -Geographical Relations of the Dune Floras." Botanical Gazette 27(2): 95-117.

Daly, C., M. Halbleib, J. I. Smith, W. P. Gibson, M. K. Doggett, G. H. Taylor, J. Curtis and P. P. Pasteris (2008). "Physiographically sensitive mapping of climatological temperature and precipitation across the conterminous United States." International Journal of Climatology 28(15): 2031-2064.

De Deyn, G. B., J. H. C. Cornelissen and R. D. Bardgett (2008). "Plant functional traits and soil carbon sequestration in contrasting biomes." Ecology Letters 11(5): 516531.

Duda, J. J., D. C. Freeman, J. M. Emlen, J. Belnap, S. G. Kitchen, J. C. Zak, E. Sobek, M. Tracy and J. Montante (2003). "Differences in native soil ecology associated with invasion of the exotic annual chenopod, Halogeton glomeratus." Biology and Fertility of Soils 38(2): 72-77.

Emery, S. M., L. Bell-Dereske and J. A. Rudgers (2015). "Fungal symbiosis and precipitation alter traits and dune building by the ecosystem engineer, Ammophila breviligulata." Ecology 96(4): 927-935.

Emery, S. M. and P. J. Doran (2013). "Presence and management of the invasive plant Gypsophila paniculata (baby's breath) on sand dunes alters arthropod abundance and community structure." Biological Conservation 161: 174-181.

Emery, S. M., P. J. Doran, J. T. Legge, M. Kleitch and S. Howard (2013). "Aboveground and Belowground Impacts Following Removal of the Invasive Species Baby's Breath (Gypsophila paniculata) on Lake Michigan Sand Dunes." Restoration Ecology 21(4): 506-514.

ESRI (2011). ArcGIS Desktop: Release 10. Redlands, CA, Environemtnal Systems Research Institute.

Fierer, N. and R. B. Jackson (2006). "The diversity and biogeography of soil bacterial communities." Proceedings of the National Academy of Sciences of the United States of America 103(3): 626-631.

Fons, F., N. Amellal, C. Leyval, N. Saint-Martin and M. Henry (2003). "Effects of gypsophila saponins on bacterial growth kinetics and on selection of subterranean clover rhizosphere bacteria." Canadian Journal of Microbiology 49(6): 367-373.

Gronewold, A. D., V. Fortin, B. Lofgren, A. Clites, C. A. Stow and F. Quinn (2013). "Coasts, water levels, and climate change: A Great Lakes perspective." Climatic Change 120(4): 697-711.

Klironomos, J. N. (2002). "Feedback with soil biota contributes to plant rarity and invasiveness in communities." Nature 417(6884): 67-70. 
Kourtev, P. S., J. G. Ehrenfeld and M. Haggblom (2002). "Exotic plant species alter the microbial community structure and function in the soil." Ecology 83(11): 31523166.

Kumar, M., M. K. Mannisto, J. D. van Elsas and R. M. Nissinen (2016). "Plants impact structure and function of bacterial communities in Arctic soils." Plant and Soil 399(1-2): 319-332.

Kuske, C. R., L. O. Ticknor, M. E. Miller, J. M. Dunbar, J. A. Davis, S. M. Barns and J. Belnap (2002). "Comparison of soil bacterial communities in rhizospheres of three plant species and the interspaces in an arid grassland." Applied and Environmental Microbiology 68(4): 1854-1863.

Larkin, D. J. (2012). "Lengths and correlates of lag phases in upper-Midwest plant invasions." Biological Invasions 14(4): 827-838.

Ledgard, S. F. and K. W. Steele (1992). "Biological Nitrogen-Fixation in Mixed Legume Grass Pastures." Plant and Soil 141(1-2): 137-153.

Leege, L. M. and J. S. Kilgore (2014). "Recovery of Foredune and Blowout Habitats in a Freshwater Dune Following Removal of Invasive Austrian Pine (Pinus nigra)." Restoration Ecology 22(5): 641-648.

Lichter, J. (1998). "Primary succession and forest development on coastal Lake Michigan sand dunes." Ecological Monographs 68(4): 487-510.

Lugtenberg, B. and F. Kamilova (2009). Plant-Growth-Promoting Rhizobacteria. Annual Review of Microbiology. 63: 541-556.

McCune (1999). PC-ORD: Multivariate Analysis of Ecological Data. Glenden Beach, Oregon USA, MjM Software.

McCune (2002). Analysis of Ecological Communities. Gleneden Beach, Oregon, MjM Software Design.

Pennanen, T., R. Strommer, A. Markkola and H. Fritze (2001). "Microbial and plant community structure across a primary succession gradient." Scandinavian Journal of Forest Research 16(1): 37-43.

Ramirez (2011). "Consistent effects of nitrogen fertilization on soil bacterial communities in contrasting systems (vol 91, pg 3463, 2010)." Ecology 92(6): 1384-1384.

Reid, M. L. and S. M. Emery (2017). "Native and exotic foundation grasses differ in traits and responses to belowground tri-trophic interactions." Plant Ecology 218(2): 173-183.

Reinhart, K. O. and R. M. Callaway (2006). "Soil biota and invasive plants." New Phytologist 170(3): 445-457. 
Rietl, A. J., M. E. Overlander, A. J. Nyman and C. R. Jackson (2016). "Microbial Community Composition and Extracellular Enzyme Activities Associated with Juncus roemerianus and Spartina alterniflora Vegetated Sediments in Louisiana Saltmarshes." Microbial Ecology 71(2): 290-303.

Ryan, M. G., J. M. Melillo and A. Ricca (1990). "A Comparison of Methods for Determining Proximate Carbon Fractions of Forest Litter." Canadian Journal of Forest Research-Revue Canadienne De Recherche Forestiere 20(2): 166-171.

Setala, H. and M. A. McLean (2004). "Decomposition rate of organic substrates in relation to the species diversity of soil saprophytic fungi." Oecologia 139(1): 98107.

Shukla, K. P., S. Sharma, N. K. Singh, V. Singh, K. Tiwari and S. Singh (2011). "Nature and role of root exudates: Efficacy in bioremediation." African Journal of Biotechnology 10(48): 9717-9724.

Smalla, K., G. Wieland, A. Buchner, A. Zock, J. Parzy, S. Kaiser, N. Roskot, H. Heuer and G. Berg (2001). "Bulk and rhizosphere soil bacterial communities studied by denaturing gradient gel electrophoresis: Plant-dependent enrichment and seasonal shifts revealed." Applied and Environmental Microbiology 67(10): 4742-4751.

Tarlera, S., K. Jangid, A. H. Ivester, W. B. Whitman and M. A. Williams (2008). "Microbial community succession and bacterial diversity in soils during 77,000 years of ecosystem development." Fems Microbiology Ecology 64(1): 129-140.

Tscherko, D., J. Rustemeier, A. Richter, W. Wanek and E. Kandeler (2003). "Functional diversity of the soil microflora in primary succession across two glacier forelands in the Central Alps." European Journal of Soil Science 54(4): 685-696.

van der Heijen, M. G. A. (2008). "The unseen majority: Soil microbes as drivers of plant diversity and productivity in terrestrial ecosystems (vol 11, pg 296, 2008)." Ecology Letters 11(6): 651-651.

Vranova, V., K. Rejsek, K. R. Skene, D. Janous and P. Formanek (2013). "Methods of collection of plant root exudates in relation to plant metabolism and purpose: A review." Journal of Plant Nutrition and Soil Science 176(2): 175-199.

Zhang, X. M., G. M. Zhang, Q. S. Chen and X. G. Han (2013). "Soil Bacterial Communities Respond to Climate Changes in a Temperate Steppe." Plos One 8(11).

Zogg, G. P., D. R. Zak, D. B. Ringelberg, N. W. MacDonald, K. S. Pregitzer and D. C. White (1997). "Compositional and functional shifts in microbial communities due to soil warming." Soil Science Society of America Journal 61(2): 475-481. 


\section{CURRICULUM VITA}

NAME:

ADDRESS:

DOB:

EDUCATION

AND TRAINING:

AWARDS:

PROFESSIONAL SOCIETIES:
EDUCATION

Andrea Stark Howes

1128 S $3^{\text {rd }}$ Street, Apt 4

Louisville, KY 40203

Florence, Kentucky- November 24, 1992

B.S., Biology

University of Louisville

2011-2015

Stuart E. Neff Award, University of Louisville

2014-2015

Kentucky Academy of Science Member 2016

PRESENTATIONS: Kentucky Academy of Science Symposium "Environmental factors contribute to functional diversity of soil bacteria in the dunes of Lake Michigan"

September, 2016 